\title{
Link between lipid metabolism and voluntary food intake in rainbow trout fed coconut oil rich in medium-chain TAG
}

\author{
A. Cláudia Figueiredo-Silva ${ }^{1}$, Sadasivam Kaushik ${ }^{1}$, Frédéric Terrier ${ }^{1}$, Johan W. Schrama ${ }^{2}$, \\ Françoise Médale ${ }^{1}$ and Inge Geurden ${ }^{1 *}$ \\ ${ }^{1}$ INRA, UR1067, Nutrition, Metabolism and Aquaculture, Pôle d'Hydrobiologie INRA, F-64310 St. Pée-sur-Nivelle, France \\ ${ }^{2}$ Aquaculture and Fisheries Group, Wageningen University, PO Box 338, 6700 AH Wageningen, The Netherlands
}

(Submitted 9 May 2011 - Final revision received 21 July 2011 - Accepted 22 July 2011 - First published online 29 September 2011)

\begin{abstract}
We examined the long-term effect of feeding coconut oil (CO; rich in lauric acid, C12) on voluntary food intake and nutrient utilisation in rainbow trout (Oncorbynchus mykiss), with particular attention to the metabolic use (storage or oxidation) of ingested medium-chain TAG. Trout were fed for 15 weeks one of the four isoproteic diets containing fish oil (FO) or CO as fat source (FS), incorporated at $5 \%$ (low fat, $\mathrm{LF}$ ) or $15 \%$ (high fat, HF). Fat level or FS did not modify food intake $\left(\mathrm{g} / \mathrm{kg}^{0-8}\right.$ per d), despite higher intestinal cholecystokinin-T mRNA in trout fed the HF-FO diet. The HF diets relative to the LF ones induced higher growth and adiposity, whereas the replacements of FO by CO resulted in similar growth and adiposity. This, together with the substantial retention of $\mathrm{C} 12$ (57\% of intake), suggests the relatively low oxidation of ingested C12. The down-regulation of carnitine palmitoyl-transferase-1 (CPT-1) confirms the minor dependency of mediumchain fatty acids (MCFA) on CPT-1 to enter the mitochondria. However, MCFA did not up-regulate mitochondrial oxidation evaluated using hepatic hydroxyacyl-CoA dehydrogenase as a marker, in line with their high retention in body lipids. At a low lipid level, MCFA increased mRNA levels of fatty acid synthase, elongase and stearoyl-CoA desaturase in liver, showing the hepatic activation of fatty acid synthesis pathways by MCFA, reflected by increased 16:0, 18:0,16:1, 18:1 body levels. The high capacity of trout to incorporate and transform $\mathrm{C} 12$, rather than to readily oxidise $\mathrm{C} 12$, contrasts with data in mammals and may explain the absence of a satiating effect of CO in rainbow trout.
\end{abstract}

Key words: Medium-chain fatty acids: Coconut oil: Fatty acid oxidation: Satiety

Medium-chain fatty acids (MCFA), which are the principal constituents of medium-chain TAG (MCT), are saturated with a chain length of six to twelve carbons ${ }^{(1,2)}$. In mammalian vertebrates, the consumption of MCT has been reported to decrease food intake ${ }^{(3-5)}$ and to reduce fat deposition ${ }^{(6,7)}$. The satiety effect of MCT compared with long-chain TAG has been attributed to the metabolic discrimination in fatty acid utilisation. Long-chain fatty acids (LCFA), after being packed into chylomicrons, enter the lymphatic system that favours their uptake by peripheral tissues such as adipose tissues and muscle ${ }^{(1,2)}$. In contrast, MCFA can enter directly into the portal vein that accelerates their uptake and oxidation by the liver. As a result, minor amounts of MCFA are recovered in the different tissues ${ }^{(8,9)}$. Moreover, the transport of MCFA across the mitochondrial membrane does not require carnitine palmitoyltransferase- 1 (CPT- 1$)^{(10)}$, considered as a rate-limiting step in the mitochondrial oxidation of LCFA.
In this context, the satiating effect of MCFA has been explained by their rapid oxidation and the limited 'storage' of MCFA by the organism. The possible link between oxidative metabolism, satiety and food intake has been documented in rats and human subjects ${ }^{(11-13)}$, but has been little studied in growing teleost fish.

The use of MCT as a dietary lipid source, supplied either as a blend of $\mathrm{C} 8$ and $\mathrm{C} 10^{(14-16)}$ or in the form of C12-rich Coconut oil $(\mathrm{CO})^{(17-21)}$ or both $^{(22,23)}$, has been evaluated in several species of farmed fish, mainly in view of the replacement of fish oil (FO) derived from wild-caught marine resources. Overall, the digestibility of MCT appears high $(>85 \%)$ in both warm-water ${ }^{(21)}$ and cold-water fish species $^{(16,17,24)}$. Data on MCT utilisation for growth or energy are more controversial. Moreover, since most applied a fixed feeding ration $^{(14,19,22)}$ or used small fish larvae fed in excess ${ }^{(15,23)}$, only a limited number of studies have explicitly reported

Abbreviations: ACOX, acyl-CoA oxidase; CCK, cholecystokinin; CO, coconut oil; CPT-1, carnitine palmitoyltransferase-1; FAS, fatty acid synthase; FL, fat level; FO, fish oil; FS, fat source; HAD, 3-hydroxyacyl-CoA dehydrogenase; HF, high fat; LCFA, long-chain fatty acids; LF, low fat; MCFA, medium-chain fatty acids; MCT, medium-chain TAG; SCD, stearoyl-CoA desaturase.

*Corresponding author: I. Geurden, fax +33 559545152, email inge@st-pee.inra.fr 
Table 1. Ingredient and proximate composition of the diets (DM basis) fed to rainbow trout

\begin{tabular}{|c|c|c|c|c|}
\hline & \multicolumn{4}{|c|}{ Diets } \\
\hline & \multicolumn{2}{|c|}{ HF } & \multicolumn{2}{|c|}{ LF } \\
\hline & $\mathrm{CO}$ & FO & $\mathrm{CO}$ & $\mathrm{FO}$ \\
\hline \multicolumn{5}{|l|}{ Ingredients (g/kg) } \\
\hline Fishmeal $^{*}$ & 380 & 380 & 380 & 380 \\
\hline Wheat gluten $\dagger$ & 200 & 200 & 200 & 200 \\
\hline Whole wheat $\ddagger$ & 120 & 120 & 120 & 120 \\
\hline Gelatinised starch, maize $\dagger$ & 110 & 110 & 210 & 210 \\
\hline $\operatorname{co\S }$ & 150 & & 50 & \\
\hline $\mathrm{FO}^{*}$ & & 150 & & 50 \\
\hline Vitamin mix\| & 10 & 10 & 10 & 10 \\
\hline Mineral mix\| & 10 & 10 & 10 & 10 \\
\hline Binderף & 20 & 20 & 20 & 20 \\
\hline \multicolumn{5}{|l|}{ Proximate composition } \\
\hline $\mathrm{DM}(\mathrm{g} / \mathrm{kg})$ & 909 & 918 & 917 & 916 \\
\hline Crude protein (g/kg DM) & 478 & 475 & 480 & 480 \\
\hline Crude lipids (g/kg DM) & 211 & 213 & 111 & 108 \\
\hline NFE $(g / k g D M)^{\star \star}$ & 250 & 251 & 346 & 351 \\
\hline Gross energy (MJ/kg DM) & $23 \cdot 6$ & $24 \cdot 0$ & $21 \cdot 7$ & $21 \cdot 6$ \\
\hline Ash (g/kg DM) & $60 \cdot 7$ & $61 \cdot 0$ & $62 \cdot 8$ & $61 \cdot 3$ \\
\hline
\end{tabular}

HF, high-fat; LF, low-fat; CO, coconut oil; FO, fish oil; NFE, nitrogen-free extract. * Sopropêche, Lorient, France.

$\dagger$ Roquette, Lestrem, France.

\#ts Union Invivo Inzo, Argentan, France.

$\S$ Daudruy van Cauwembergher, Dunkerque, France.

|| INRA UPAE, Jouy en Josas, France.

I Sodium alginate, Louis François, Croissy Beaubourg, France.

${ }^{* *} \mathrm{NFE}=\mathrm{DM}-$ protein - fat - ash.

data on voluntary food intake. Like in homeotherms, MCFA in fish were found to result in a loss of adiposity ${ }^{(21,23)}$ and to reduce food intake in polka-dot grouper $^{(21)}$ and Atlantic salmon $^{(16)}$. Regardless of apparent species-specific differences, MCT have been shown to be more efficiently utilised by fish when provided as lauric (C12) than as caprylic (C8) $\operatorname{acid}^{(15,22,23)}$. Furthermore, the inverse relationship between MCT and food intake, growth or fat deposition seems to be exacerbated at high dietary MCT levels ${ }^{(16,21)}$.

The objective of the present long-term feeding study was to examine the relationship between voluntary food intake and nutrient utilisation for growth (body composition and circulating nutrients) in rainbow trout (Oncorbynchus mykiss), with a particular attention to the metabolic use (storage or oxidation) of the ingested lipids. For that propose, CO rich in C12 MCFA, was chosen to replace FO, rich in LCFA, at two incorporation levels: 5\% (low fat, LF) or 15\% (high fat, HF). Key metabolic factors involved in fatty acid synthesis and oxidation were analysed in the liver and muscle of rainbow trout in order to compare the effects of feeding MCFA and LCFA. The expression of intestinal cholecystokinin (CCK) as a function of the nutritional status was also evaluated for the first time in this species.

\section{Materials and methods \\ Diets}

In the present study, four experimental diets were formulated to be isoproteic $(480 \mathrm{~g} / \mathrm{kg}$ DM) using fishmeal as the major protein source. The fishmeal contained approximately
$80 \mathrm{~g} / \mathrm{kg}$ residual fat, which allows fulfilling the essential fatty acid requirement of rainbow trout ${ }^{(25)}$. The four diets contained either FO or $\mathrm{CO}$ as the lipid source at two incorporation levels: $5 \%$ (LF) or $15 \%$ (HF). The oils were added at the expense of gelatinised starch. The ingredient and proximate composition of the diets are presented in Table 1. Table 2 gives the details of the fatty acid profile of the diets.

\section{Growth trial}

The growth study was conducted following the Guidelines of the National Legislation on Animal Care of the French Ministry of Research (Decret no. 2001-464, 29 May 2001) and was approved by the Ethics Committee of INRA (according to INRA 2002-36, 14 April 2002). Rainbow trout were obtained and reared at the INRA experimental fish farm of Donzacq (Landes, France) in a flow-through rearing system supplied with natural spring water at constant temperature $\left(17 \pm 1^{\circ} \mathrm{C}\right)$ under natural photoperiod (October to January) conditions. Each of the four diets was carefully fed by hand to apparent satiation (two meals per d) to triplicate groups of fish $(71.3 \mathrm{~g}$ initial body weight, thirty-five individuals/tank, 350 litres/ tank). The feeding trial lasted $105 \mathrm{~d}$. The amount of food ingested by each group was recorded weekly. At the beginning (twelve fish/tank) and end (six fish/tank) of the feeding trial, a sample of $36 \mathrm{~h}$ food-deprived fish was randomly taken

Table 2. Fatty acid composition of the diets ( $\mathrm{g} / 100 \mathrm{~g}$ total fatty acid)

\begin{tabular}{|c|c|c|c|c|}
\hline & \multicolumn{4}{|c|}{ Diets } \\
\hline & \multicolumn{2}{|c|}{$\mathrm{HF}$} & \multicolumn{2}{|c|}{ LF } \\
\hline & $\mathrm{CO}$ & $\mathrm{FO}$ & $\mathrm{CO}$ & $\mathrm{FO}$ \\
\hline $10: 0$ & $3 \cdot 3$ & 0.1 & $2 \cdot 2$ & ND \\
\hline $12: 0$ & $31 \cdot 8$ & 0.7 & $19 \cdot 6$ & 0.2 \\
\hline $14: 0$ & 14.5 & $5 \cdot 8$ & $10 \cdot 7$ & 5.7 \\
\hline $16: 0$ & $11 \cdot 7$ & $16 \cdot 0$ & $12 \cdot 9$ & $16 \cdot 3$ \\
\hline $18: 0$ & $2 \cdot 8$ & $3 \cdot 3$ & $2 \cdot 6$ & $3 \cdot 0$ \\
\hline $20: 0$ & 0.1 & 0.2 & 0.1 & 0.2 \\
\hline$\Sigma$ Saturates & 64.5 & $27 \cdot 1$ & 48.5 & $26 \cdot 4$ \\
\hline $16: 1$ & $1 \cdot 2$ & 4.9 & $2 \cdot 3$ & $4 \cdot 6$ \\
\hline $18: 1$ & $10 \cdot 0$ & $15 \cdot 9$ & $10 \cdot 8$ & $14 \cdot 7$ \\
\hline $20: 1$ & $2 \cdot 2$ & $5 \cdot 4$ & 3.9 & $6 \cdot 0$ \\
\hline $22: 1$ & 3.4 & 4.5 & $6 \cdot 2$ & $7 \cdot 0$ \\
\hline$\Sigma$ MUFA & $16 \cdot 9$ & $30 \cdot 8$ & $23 \cdot 3$ & $32 \cdot 3$ \\
\hline $18: 2 n-6$ & 4.9 & $3 \cdot 8$ & $6 \cdot 3$ & $5 \cdot 7$ \\
\hline $18: 3 n-6$ & ND & 0.1 & $0 \cdot 1$ & 0.1 \\
\hline $20: 2 n-6$ & 0.1 & 0.2 & 0.2 & 0.2 \\
\hline $20: 3 n-6$ & ND & 0.1 & ND & 0.1 \\
\hline $20: 4 n-6$ & 0.2 & 0.7 & 0.3 & 0.6 \\
\hline$\Sigma n-6$ & $5 \cdot 3$ & 4.9 & 6.9 & 6.7 \\
\hline $18: 3 n-3$ & 0.5 & 0.8 & 0.8 & 1.0 \\
\hline $18: 4 n-3$ & 0.5 & 1.6 & 1.0 & 1.6 \\
\hline $20: 3 n-3$ & ND & 0.1 & 0.1 & 0.1 \\
\hline $20: 4 n-3$ & 0.2 & 0.8 & 0.4 & 0.7 \\
\hline $20: 5 n-3$ & $2 \cdot 2$ & $9 \cdot 4$ & $4 \cdot 0$ & $8 \cdot 1$ \\
\hline $22: 5 n-3$ & 0.2 & $2 \cdot 2$ & 0.8 & 1.8 \\
\hline $22: 6 n-3$ & 1.9 & $13 \cdot 1$ & $7 \cdot 3$ & $12 \cdot 3$ \\
\hline$\sum n-3$ & $5 \cdot 6$ & $28 \cdot 6$ & 14.4 & $26 \cdot 2$ \\
\hline PUFA & 11.6 & $37 \cdot 0$ & $22 \cdot 6$ & 35.9 \\
\hline SFA:PUFA & $5 \cdot 6$ & 0.7 & $2 \cdot 2$ & 0.7 \\
\hline$\Sigma F A$ & 93.0 & 94.4 & 94.9 & 94.6 \\
\hline
\end{tabular}

HF, high-fat; LF, low-fat; CO, coconut oil; FO, fish oil; ND, not detected; FA, fatty acid. 
and stored at $-20^{\circ} \mathrm{C}$ for subsequent whole body composition analyses. At the end of the feeding trial, all fish were anaesthetised with 2-phenoxyethanol $(0 \cdot 2 \mathrm{ml} / \mathrm{l})$. Muscle, liver and foregut (nine fish/treatment) were dissected at $7 \mathrm{~h}$ postfeeding, immediately frozen in liquid $\mathrm{N}_{2}$ and stored at $-80^{\circ} \mathrm{C}$ for the subsequent analysis of enzyme activity and gene expression. Liver and viscera were weighed to calculate the hepatosomatic index and the viscerosomatic index. At 7 and $46 \mathrm{~h}$ post-feeding, blood samples were taken by caudal vein puncture and collected into tubes containing sodium fluoride (2\%) and potassium oxalate (4\%) as anticoagulant. Plasma samples, obtained after centrifugation $(3000 \boldsymbol{g}$ for $15 \mathrm{~min}$ at $4^{\circ} \mathrm{C}$ ), were stored at $-20^{\circ} \mathrm{C}$ for further analyses.

\section{Feed and whole-body analyses}

Whole fish (36h starved) were pooled per tank, ground and subsequently freeze-dried. Feed and whole-body samples were analysed for $\mathrm{DM}\left(105^{\circ} \mathrm{C}\right.$ for $\left.24 \mathrm{~h}\right)$, ash by combustion in a muffle furnace $\left(550^{\circ} \mathrm{C}\right.$ for $12 \mathrm{~h}$ ), crude protein (Kjeldahl; $\mathrm{N} \times 6 \cdot 25$, Nitrogen analyser 2000; Fison Instruments, Milan, Italy) after acid digestion and gross energy content by an adiabatic bomb calorimeter (model C5000; IKA-Werke, Heitersheim, Germany). Lipids were extracted from feed and wholebody samples according to the method of Folch and fatty acid methyl esters were determined as described previously ${ }^{(26)}$.

\section{Plasma metabolite assays}

Plasma glucose, TAG and NEFA were determined using commercial kits: 'Glucose RTU' (no. 61269) and 'Triglycérides Enzymatique' PAP 150 (no. 61236) from Bio-Mérieux (Marcy-L'Etoile, France) and 'NEFA-C' from Wako (Neuss, Germany), respectively. Plasma samples were analysed for the presence of acetoacetate following the enzymatic method as described previously ${ }^{(27)}$.

\section{Enzyme activity measurement}

Fatty acid synthase (FAS, EC 2.3.1.85) and 3-hydroxyacyl-CoA dehydrogenase (HAD, EC.1.1.1.35) activities were determined in rainbow trout liver according to Figueiredo-Silva et al. ${ }^{(26)}$ and Kolditz et $a l .{ }^{(28)}$, respectively. Enzyme activity (units IU), defined as $\mu \mathrm{mol}$ of substrate converted to product, per min, at assay temperature, is expressed per mg soluble protein (specific activity). Soluble protein content (Bradford method) was determined using a protein assay kit (Bio-Rad, Munich, Germany) and bovine serum albumin as a standard.

\section{Gene expression analysis: quantitative $R T-P C R$}

Total RNA was extracted from liver, muscle and intestine using TRIzol (Invitrogen, Carlsbad, CA, USA). For each experimental condition, nine individual samples were used as biological replicates. Total RNA was quantified by spectrophotometry (absorbance at $260 \mathrm{~nm}$ ) and integrity was controlled using the Agilent 2100 bioanalyser (Agilent Technologies, Kista, Sweden). Total RNA $(1 \mu \mathrm{g})$ was reverse-transcribed to

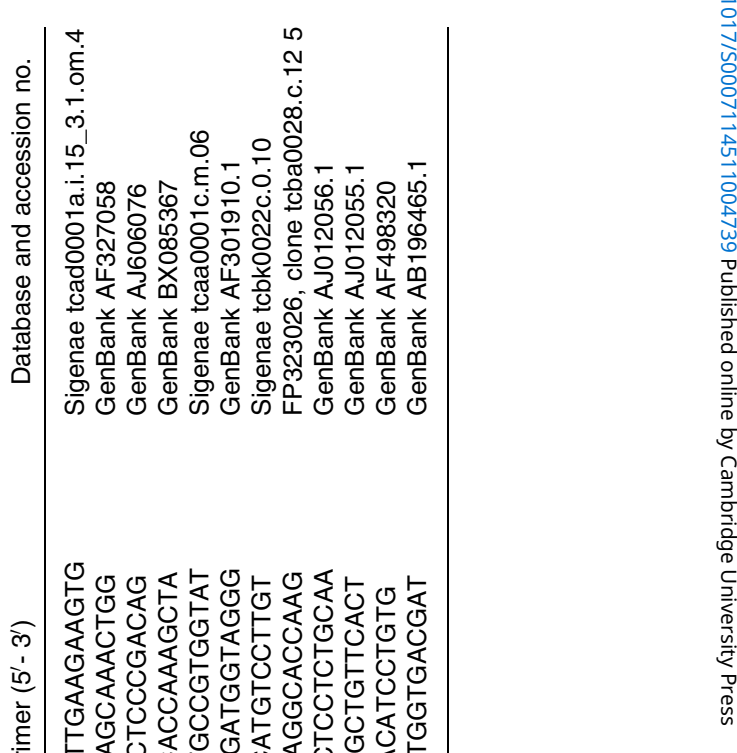


Table 4. Growth performance, feed efficiency (FE), food intake (FI) and gross energy intake (EI) of rainbow trout fed different dietary fat sources (FS) and fat levels (FL) over $105 \mathrm{~d}$ at $17 \pm 1^{\circ} \mathrm{C} \dagger$

(Mean values and standard deviations, $n 3$ )

\begin{tabular}{|c|c|c|c|c|c|c|c|c|c|c|c|}
\hline & \multicolumn{8}{|c|}{ Diets } & & & \\
\hline & \multicolumn{4}{|c|}{$\mathrm{HF}$} & \multicolumn{4}{|c|}{ LF } & & & \\
\hline & \multicolumn{2}{|c|}{$\mathrm{CO}$} & \multicolumn{2}{|c|}{$\mathrm{FO}$} & \multicolumn{2}{|c|}{$\mathrm{CO}$} & \multicolumn{2}{|c|}{ FO } & \multicolumn{3}{|c|}{$P$} \\
\hline & Mean & SD & Mean & SD & Mean & SD & Mean & SD & FS & $\mathrm{FL}$ & $\mathrm{FS} \times \mathrm{FL}$ \\
\hline Initial body weight (g) & 71.4 & 0.6 & $71 \cdot 2$ & $1 \cdot 2$ & $71 \cdot 3$ & 1.0 & $71 \cdot 2$ & $1 \cdot 2$ & NS & NS & NS \\
\hline Final body weight $(\mathrm{g})$ & 379.6 & $32 \cdot 8$ & 398.7 & $7 \cdot 8$ & $348 \cdot 2$ & $4 \cdot 13$ & 353.5 & $13 \cdot 0$ & NS & $\star \star$ & NS \\
\hline DGI & 2.9 & 0.2 & 3.1 & 0.1 & $2 \cdot 8$ & 0.04 & $2 \cdot 8$ & 0.1 & NS & ** & NS \\
\hline PER§ & $2 \cdot 2$ & 0.2 & $2 \cdot 2$ & 0.02 & 1.9 & 0.04 & 1.9 & 0.1 & NS & ** & NS \\
\hline $\mathrm{FE} \|$ & 1.0 & $0 \cdot 1$ & 1.0 & 0.01 & 0.9 & 0.02 & 0.9 & 0.02 & NS & * & NS \\
\hline $\mathrm{FI}$ (g/fish per d) & $2 \cdot 9$ & $0 \cdot 1$ & 3.0 & 0.04 & $2 \cdot 8$ & 0.01 & 2.9 & 0.03 & * & NS & NS \\
\hline $\mathrm{FI}_{\mathrm{MBW}}\left(\mathrm{g} / \mathrm{kg}^{-0.8}\right.$ per $\left.\mathrm{d}\right) \boldsymbol{q}$ & $12 \cdot 1$ & 0.4 & $12 \cdot 6$ & 0.2 & 12.5 & 0.03 & $12 \cdot 6$ & 0.2 & NS & NS & NS \\
\hline $\mathrm{EI}_{\mathrm{MBW}}\left(\mathrm{kJ} / \mathrm{kg}^{-0.8}\right.$ per d) & $315 \cdot 8$ & $9 \cdot 9$ & $327 \cdot 8$ & $4 \cdot 1$ & 294.4 & 0.8 & $296 \cdot 1$ & $7 \cdot 2$ & NS & ** & NS \\
\hline
\end{tabular}

HF, high-fat; LF, low-fat; CO, coconut oil; FO, fish oil; DGI, daily growth index; PER, protein efficiency ratio; MBW, metabolic body weight.

$P$-value for FS, FL and interaction between the main effects of the two tested factors (FS $v$. FL) are as follows: ${ }^{*} P<0.05 ;{ }^{\star \star} P<0.01$ (two-way ANOVA).

$\dagger$ Mean values with no unlike superscript letters indicate no significant interaction between the two dietary factors (FS and FL; $P>0.05$ ).

$\neq D G I=100 \times\left((\text { final body weight })^{1 / 3}-(\text { initial body weight })^{1 / 3}\right)$ per $\mathrm{d}$.

SPER = wet weight gain/crude protein intake.

$\| \mathrm{FE}=$ wet weight gain/dry feed intake.

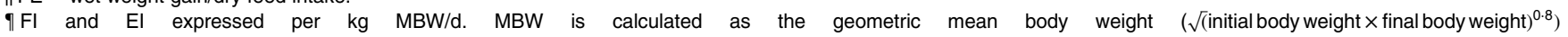
$\left(\sqrt{(\text { initial body weight } \times \text { final body weight } / 1000)^{0.8}}\right)$.

complementary DNA with the SuperScript III RNase H reverse transcriptase kit (Invitrogen) using oligo(dT)15 primers (Promega, Madison, WI, USA). Reverse transcription of each RNA extract was performed in duplicate. Real-time PCR was performed with the iCycler iQ (Bio-Rad, Hercules, CA, USA) on triplicates of $10 \mu \mathrm{l}$ of the RT reaction mixtures using the iQ SYBR green Supermix (Bio-Rad). The total volume of the PCR mixture was $25 \mu \mathrm{l}$, containing $200 \mathrm{~nm}$ of primers. Gene abbreviations, database accession numbers and the sequences of the forward and reverse primers used for the analysis of gene expression are shown in Table 3. The stearoyl-CoA desaturase (SCD) unannotated sequence of rainbow trout (FP323026.1) was identified based on sequence similarities with annotated SCD sequences from other species, i.e. Atlantic salmon, Salmo salar (National Center for Biotechnology Information (NCBI), NM_001139980), common carp, Cyprinus carpio (GenBank $\mathrm{U} 31864.2$ and $\mathrm{AJ} 249259.1$ ) and zebrafish, Danio rerio (NM_198815). Specific primers for SCD- and CCK-like pairs were designed using Primer3 software and chosen to contain an overlapping intron when possible, using known sequences in nucleotide databases (GenBank and National Institute of Agronomic Research INRA-Sigenae; http://www.sigenae.org/ ). SCD- and CCK-like PCR products were run on a $2 \%$ agarose gel to check that only one fragment was amplified (i.e. absence of genomic DNA amplification) and sequenced to ensure that the correct mRNA sequences were quantified.

A total of thirty-five steps of PCR were performed, each one consisting of heating at $95^{\circ} \mathrm{C}$ for $20 \mathrm{~s}$ for denaturing, and at $55^{\circ} \mathrm{C}(\mathrm{CPT} 1), 59^{\circ} \mathrm{C}(\beta$-actin, elongation factor $1-\alpha$, HAD and SCD) or $60^{\circ} \mathrm{C}$ (acyl-CoA oxidase (ACOX), delta-6-desaturase, CCK, fatty-acyl-chain elongase protein 3 and FAS) for $30 \mathrm{~s}$, for annealing and extension. After the final cycle of the PCR, melting curves were systematically monitored (increasing set-point temperature from 59 to $95^{\circ} \mathrm{C}$ by $0.5^{\circ} \mathrm{C} / 10 \mathrm{~s}$ ). Negative controls (sample without RT and samples without RNA) were run for each reaction. mRNA levels of the target genes in muscle and liver were normalised to the housekeeping gene $\alpha$-elongation factor 1 , and those in the intestine (for CCKlike peptides) to $\beta$-actin. Expression levels were calculated using the mathematical model described previously ${ }^{(28)}$

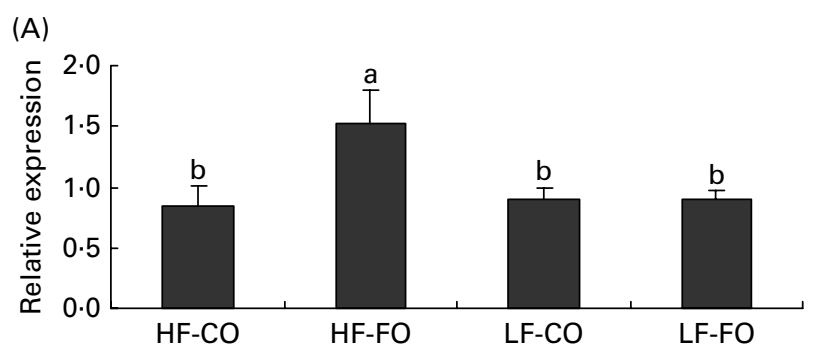

(B)

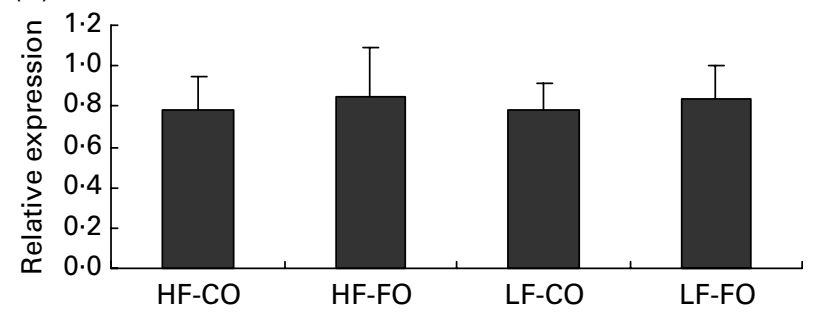

Fig. 1. Postprandial $(7 \mathrm{~h})$ gene expression of $(A)$ cholecystokinin (CCK)-Tand (B) CCK-L-like peptides in the intestine of rainbow trout fed during the 15-week feeding trial with different fat sources (FS: coconut oil (CO) or fish oil (FO)) and fat levels (FL: high fat (HF) or low fat (LF)). Values are means, with their standard errors represented by vertical bars, $n$ 9. Expression values are normalised to the expressed $\beta$-actin transcripts. Statistical significance for the two independent factors, FS and FL, and their interaction are indicated as follows: FS, $P<0.05$; FL, $P<0.05$; FS $\times \mathrm{FL}, P<0.05$. Mean values with no unlike letters indicate no significant interaction between the two dietary factors (FS v. FL; $P>0.05)$. ${ }^{a, b}$ Mean values with unlike letters were significantly different $(P<0.05)$. 


\section{Statistical analysis}

Statistical analyses were performed using STATISTICA 7.0 (StatSoft Inc., Tulsa, OK, USA). All data were tested for normality and homogeneity of variances by KolmogorovSmirnov and Bartlett tests, and then subjected to a two-way ANOVA, using fat source (FS) and fat level (FL) as independent factors. When the interaction between FS and FL was significant $(P<0.05)$, individual means were compared using Tukey's honestly significant difference test.

\section{Results}

At the end of the 15-week feeding trial, the dietary FL (210 $v$. $110 \mathrm{~g} / \mathrm{kg}$ ), but not the dietary FS (CO $v$. FO) significantly affected rainbow trout growth performance (Table 4). Irrespective of the FS, fish fed HF diets compared with LF diets had higher final body weight, with improved daily growth index, protein efficiency ratio and feed efficiency. Daily food intake was significantly affected by the FS when expressed per individual. However, when corrected for the metabolic weight of the fish, food intakes of the four diets were found to be similar (Table 4). Energy intake was higher with HF diets, reflecting the higher energy content of those diets. The dietary FS and, to a lesser extent, the FL affected the intestinal expression of CCK-T, however, with a significant interaction between the two factors (Fig. 1). This interaction is related to the fact that the stimulating effect of FO on CCK-T was only seen with the HF diets and not with the LF diets. No significant differences between the groups were found for $C C K$ - $L$-like gene expression (Fig. 1).

As seen for growth parameters, final body composition was significantly affected by the FL but not by the FS (Table 5). Whole-body lipid content and lipid and protein gain were higher in fish fed the HF diets than in fish fed the LF diets, with an opposite trend for whole-body moisture and relative protein content. The reduced body lipid content in LF-fed fish was associated with a reduced viscerosomatic index, particularly when fed the LF-CO diet. Fish hepatosomatic index was unaffected by the dietary treatments (Table 5). Irrespective of the FS, the retention of protein (\%, gain/ intake) was slightly improved by the HF level, whereas that of lipid was higher with the LF diets. An effect of both FS

Table 5. Whole body composition ( $\mathrm{g} / 100 \mathrm{~g}$ body weight (BW)), nutrient gain ( $\mathrm{g} / \mathrm{fish})$, nutrient retention and plasma metabolites in rainbow trout fed diets with different fat sources (FS) and fat levels (FL)

(Mean values and standard deviations, $n 3$ or 9 for plasma metabolites)

\begin{tabular}{|c|c|c|c|c|c|c|c|c|c|c|c|}
\hline & \multicolumn{8}{|c|}{ Diets } & & & \\
\hline & \multicolumn{4}{|c|}{$\mathrm{HF}$} & \multicolumn{4}{|c|}{ LF } & & & \\
\hline & \multicolumn{2}{|c|}{$\mathrm{CO}$} & \multicolumn{2}{|c|}{$\mathrm{FO}$} & \multicolumn{2}{|c|}{$\mathrm{CO}$} & \multicolumn{2}{|c|}{$\mathrm{FO}$} & \multicolumn{3}{|c|}{$P$} \\
\hline & Mean & SD & Mean & SD & Mean & SD & Mean & SD & FS & $\mathrm{FL}$ & $\mathrm{FS} \times \mathrm{FL}$ \\
\hline \multicolumn{12}{|c|}{ Final body composition $†$} \\
\hline Moisture (g/100 g) & $68 \cdot 8$ & 0.7 & $68 \cdot 3$ & 0.5 & $70 \cdot 6$ & 0.7 & $70 \cdot 3$ & 0.4 & NS & ** & NS \\
\hline Protein $(\mathrm{g} / 100 \mathrm{~g})$ & $16 \cdot 8$ & 0.4 & $17 \cdot 0$ & 0.3 & $17 \cdot 4$ & 0.5 & $17 \cdot 6$ & $0 \cdot 1$ & NS & * & NS \\
\hline Lipid (g/100 g) & $12 \cdot 4$ & 0.8 & $12 \cdot 8$ & 0.7 & $9 \cdot 7$ & 0.4 & $9 \cdot 6$ & 0.3 & NS & $\star \star$ & NS \\
\hline Ash $(\mathrm{g} / 100 \mathrm{~g})$ & $2 \cdot 0$ & 0.03 & 1.9 & 0.1 & $2 \cdot 0$ & $0 \cdot 1$ & $2 \cdot 1$ & $0 \cdot 1$ & ** & NS & NS \\
\hline HSI (\%)‡ & $1 \cdot 2$ & $0 \cdot 1$ & $1 \cdot 1$ & 0.2 & $1 \cdot 2$ & 0.2 & $1 \cdot 1$ & 0.2 & NS & NS & NS \\
\hline VSI (\%)§ & $8 \cdot 0$ & 0.9 & $7 \cdot 3$ & $1 \cdot 2$ & $5 \cdot 9$ & 0.5 & $6 \cdot 3$ & 0.7 & NS & $\star \star$ & ${ }^{*} \|$ \\
\hline Protein gain $(\mathrm{g})$ & $52 \cdot 1$ & $4 \cdot 6$ & $56 \cdot 0$ & 1.0 & $49 \cdot 0$ & 1.5 & $50 \cdot 8$ & $2 \cdot 1$ & NS & * & NS \\
\hline Lipid gain (g) & 41.5 & $5 \cdot 3$ & $45 \cdot 1$ & 2.9 & $28 \cdot 1$ & 1.5 & $28 \cdot 3$ & $2 \cdot 3$ & NS & ** & NS \\
\hline $\mathrm{C} 12$ gain $(\mathrm{g})$ & $10 \cdot 9^{a}$ & 0.8 & $0 \cdot 2^{\mathrm{c}}$ & 0.02 & $3.9^{b}$ & 0.01 & $0 \cdot 1^{c}$ & 0.01 & $\star *$ & ** & $\star \star$ \\
\hline \multicolumn{12}{|l|}{ Retention (\% intake) } \\
\hline Protein & $36 \cdot 2$ & $2 \cdot 2$ & $37 \cdot 2$ & 0.4 & $34 \cdot 2$ & 0.9 & $34 \cdot 7$ & 1.6 & NS & * & NS \\
\hline Lipid & 65.4 & $6 \cdot 2$ & $66 \cdot 8$ & $4 \cdot 0$ & $85 \cdot 0$ & $4 \cdot 2$ & $86 \cdot 3$ & $7 \cdot 6$ & NS & ** & NS \\
\hline C12 & $57 \cdot 2^{b}$ & 2.9 & $39 \cdot 9^{b}$ & 3.6 & $56 \cdot 4^{b}$ & $4 \cdot 0$ & $173 \cdot 8^{a}$ & $18 \cdot 3$ & $\star \star$ & ** & $\star \star$ \\
\hline \multicolumn{12}{|l|}{ Plasma metabolites } \\
\hline \multicolumn{12}{|l|}{ Glucose $(g / l)$} \\
\hline $7 \mathrm{~h}$ & $1 \cdot 158$ & 0.285 & $1 \cdot 161$ & 0.174 & $1 \cdot 191$ & 0.278 & 1.049 & 0.153 & NS & NS & NS \\
\hline $46 \mathrm{~h}$ & 1.575 & 0.340 & 1.059 & 0.360 & 0.859 & 0.305 & 0.834 & 0.233 & NS & $\star \star$ & NS \\
\hline \multicolumn{12}{|l|}{ NEFA (mEq/l) } \\
\hline $7 \mathrm{~h}$ & $0.49^{a}$ & 0.17 & $0.22^{b}$ & 0.05 & $0 \cdot 19^{b}$ & 0.03 & $0 \cdot 17^{\mathrm{b}}$ & 0.02 & $\star *$ & ** & $\star \star$ \\
\hline $46 \mathrm{~h}$ & 0.60 & $0 \cdot 10$ & 0.39 & $0 \cdot 10$ & 0.40 & 0.12 & 0.32 & $0 \cdot 10$ & $\star \star$ & ** & NS \\
\hline \multicolumn{12}{|l|}{ TAG $(g / l)$} \\
\hline $7 \mathrm{~h}$ & $6 \cdot 2$ & 2.4 & $4 \cdot 5$ & $1 \cdot 0$ & $6 \cdot 4$ & $1 \cdot 0$ & $4 \cdot 0$ & 1.5 & ** & NS & NS \\
\hline $46 \mathrm{~h}$ & $4 \cdot 8$ & $1 \cdot 7$ & $4 \cdot 2$ & $1 \cdot 0$ & $3 \cdot 0$ & $1 \cdot 0$ & $2 \cdot 7$ & 0.9 & NS & ** & NS \\
\hline \multicolumn{12}{|l|}{ Acetoacetate (mм) } \\
\hline $7 \mathrm{~h}$ & 0.41 & 0.06 & 0.31 & 0.06 & 0.35 & 0.06 & 0.37 & 0.05 & NS & NS & ${ }^{*} \|$ \\
\hline $46 \mathrm{~h}$ & $0.41^{a}$ & 0.05 & $0.23^{b}$ & $0 \cdot 10$ & $0.21^{b}$ & 0.12 & $0.33^{a, b}$ & 0.07 & NS & NS & $\star \star$ \\
\hline
\end{tabular}

HF, high-fat; LF, low-fat; CO, coconut oil; FO, fish oil; HIS, hepatosomatic index; VSI, viscerosomatic index.

a,b,c Mean values within a row with unlike superscript letters showed a significant interaction between the two tested factors (FS $v$. FL; $P<0.05)$

$P$ value for FS, FL and interaction between the main effects of the two tested factors (FS $v$. FL): ${ }^{*} P<0.05 ;{ }^{* \star} P<0.01$ (two-way ANOVA).

†Initial body composition (percentage of whole BW): moisture $73.3 \%$; protein $16 \cdot 2 \%$; lipid $8.1 \%$.

$\ddagger \mathrm{HSI}=100 \times$ liver weight/final BW.

$\S \mathrm{VSI}=100 \times$ weight of viscera/final BW.

$\|$ Without significant differences after post hoc analysis. 
and FL was observed for the amount of C12 incorporated by the animal, in absolute ( $\mathrm{g}$ /individual) as well as in relative (\%, gain/intake) terms. Here, the apparently high relative retention in the LF-FO group is to be attributed to the very low amount of $\mathrm{C} 12$ in the LF-FO diet. It was observed that $57 \%$ of the ingested C12 was recovered in the body lipids of trout fed with the CO diets (Table 5).

Whole-body fatty acid composition of rainbow trout fed the different diets is shown in Table 6. Except for some minor fatty acids, the whole-body fatty acid profile (percentage of total fatty acids) of the trout reflected in general terms that of the diets. The proportion of SFA was almost twice higher in fish fed the CO diets (53 and 40\% with the HF-CO and LF-CO diets, respectively) than in fish fed the FO diets (27\% with both LF-FO and HF-FO diets), mainly due to the efficient C12 and $\mathrm{C} 16$ retention. Surprisingly, more than 20\% (percentage of total fatty acids) of the fatty acids in fish fed the HF-CO diet were $\mathrm{C} 12$ compared with $<1 \%$ in fish fed the HF-FO diet. Fish fed the FO diets had higher MUFA and PUFA, reflecting the higher dietary levels. In addition, MUFA percentages were higher in fish fed the LF diets, irrespective of the FS (Table 6).

Selected key enzymes of lipid metabolism were analysed for activity in the liver (Fig. 2) and for gene expression in the liver
(Fig. 3) and muscle (Fig. 4). Both hepatic FAS activity and FAS mRNA expression were affected by the interaction between the FS and the FL, being higher in fish fed the LF-CO diet. In muscle, FAS mRNA expression was significantly decreased by feeding the HF diets compared with the LF diets, but unaffected by the FS. A significant interaction between the FS and the FL was observed for fatty-acyl-chain elongase protein 3 and SCD expressions in liver, being higher in fish fed the LF-CO diet, whereas liver delta-6-desaturase expressions were unaffected by the diet (Fig. 3).

Regarding the markers involved in fatty acid oxidation, both CPT1-b and ACOX mRNA expressions in liver showed a significant interaction between the FS and the FL, being higher in fish fed the HF-FO diet (Fig. 3). The increased hepatic HAD activity (Fig. 2) in trout fed the HF diets was not reflected in terms of HAD expression (Fig. 3). As for CPT1-b, the expression of CPT1-a isoform in liver was affected by the FS, being lower in fish fed the CO diets, but without affected by the FL (Fig. 3). The effect of the diets on the expression of fatty acid oxidation markers was less pronounced in muscle than in liver. The expression of ACOX and CPT1-a was not affected by the dietary treatment in muscle, while a significant effect of both FS and FL was found for CPT1-b.

Table 6. Whole-body fatty acid composition ( $\mathrm{g} / 100 \mathrm{~g}$ total fatty acids) in rainbow trout fed diets with different fat sources (FS) and fat levels (FL) (Mean values and standard deviations, $n$ 9)

\begin{tabular}{|c|c|c|c|c|c|c|c|c|c|c|c|}
\hline & \multicolumn{8}{|c|}{ Diets } & & & \\
\hline & \multicolumn{4}{|c|}{$\mathrm{HF}$} & \multicolumn{4}{|c|}{ LF } & & & \\
\hline & \multicolumn{2}{|c|}{$\mathrm{CO}$} & \multicolumn{2}{|c|}{ FO } & \multicolumn{2}{|c|}{$\mathrm{CO}$} & \multicolumn{2}{|c|}{ FO } & \multicolumn{3}{|c|}{$P$} \\
\hline & Mean & SD & Mean & SD & Mean & SD & Mean & SD & FS & $\mathrm{FL}$ & $\mathrm{FS} \times \mathrm{FL}$ \\
\hline $10: 0$ & 1.5 & $0 \cdot 1$ & ND & & 0.6 & 0.1 & ND & & - & - & - \\
\hline $12: 0$ & $21 \cdot 0^{\mathrm{a}}$ & 0.7 & $0.3^{\mathrm{c}}$ & 0.01 & $10 \cdot 3^{b}$ & 0.7 & $0.3^{c}$ & 0.02 & 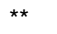 & ** & ** \\
\hline $14: 0$ & $11 \cdot 7^{\mathrm{a}}$ & 0.02 & $4.9^{c}$ & 0.1 & $7 \cdot 7^{\mathrm{b}}$ & 0.3 & $4 \cdot 2^{\mathrm{d}}$ & 0.1 & ** & ** & ** \\
\hline $16: 0$ & $15 \cdot 1^{\mathrm{b}}$ & 0.5 & $17 \cdot 0^{a}$ & 0.4 & $17 \cdot 1^{\mathrm{a}}$ & 0.3 & $17 \cdot 7^{a}$ & 0.5 & $* *$ & * & * \\
\hline $18: 0$ & 3.5 & 0.2 & 3.5 & 0.02 & 3.8 & 0.04 & 3.8 & 0.1 & NS & ** & NS \\
\hline $20: 0$ & 0.1 & 0.01 & 0.1 & 0.04 & 0.1 & 0.03 & 0.2 & 0.02 & $\star *$ & * & NS \\
\hline Saturates & $53 \cdot 2^{a}$ & 0.6 & $26 \cdot 7^{c}$ & 0.5 & $40 \cdot 0^{\mathrm{b}}$ & 0.8 & $26 \cdot 8^{c}$ & 0.4 & $\star \star$ & ** & ** \\
\hline $16: 1$ & $4 \cdot 0^{c}$ & 0.2 & $6 \cdot 2^{\mathrm{a}}$ & 0.1 & $5 \cdot 5^{\mathrm{b}}$ & 0.4 & $6 \cdot 2^{\mathrm{a}}$ & 0.3 & ** & * & ** \\
\hline $18: 1$ & $18 \cdot 8$ & 0.7 & 18.9 & 0.2 & $22 \cdot 6$ & 0.4 & $21 \cdot 7$ & 0.4 & NS & ** & NS \\
\hline $20: 1$ & $2 \cdot 1^{\mathrm{C}}$ & 0.1 & $3 \cdot 2^{b}$ & 0.1 & $3.0^{\mathrm{b}}$ & 0.01 & $3 \cdot 6^{a}$ & 0.2 & $\star *$ & ** & $* *$ \\
\hline $22: 1$ & $1 \cdot 5^{\mathrm{c}}$ & 0.1 & $2 \cdot 3^{b}$ & 0.1 & $2 \cdot 5^{\mathrm{b}}$ & 0.1 & $2.9^{a}$ & 0.1 & $\star \star *$ & ** & ** \\
\hline MUFA & $26 \cdot 6^{\mathrm{c}}$ & 0.9 & $30 \cdot 7^{b}$ & 0.2 & $33 \cdot 6^{\mathrm{a}}$ & 0.9 & $34.5^{\mathrm{a}}$ & 0.2 & ** & ** & ** \\
\hline $18: 2 n-6$ & 5.5 & 0.2 & $5 \cdot 2$ & 0.1 & $7 \cdot 0$ & 0.1 & 6.4 & 0.1 & $\star *$ & ** & NS \\
\hline $18: 3 n-6$ & $0 \cdot 16^{b}$ & 0.002 & $0.15^{\mathrm{b}}$ & 0.01 & $0 \cdot 18^{a}$ & 0.01 & $0.13^{\mathrm{c}}$ & 0.05 & $\star \star$ & NS & ** \\
\hline $20: 2 n-6$ & 0.4 & $0 \cdot 1$ & 0.4 & 0.02 & 0.5 & 0.01 & 0.5 & 0.02 & NS & ** & NS \\
\hline $20: 3 n-6$ & 0.2 & 0.01 & 0.2 & 0.01 & 0.3 & 0.03 & 0.3 & 0.01 & NS & ** & NS \\
\hline $20: 4 n-6$ & $0.3^{d}$ & 0.004 & $0.7^{\mathrm{a}}$ & 0.01 & $0.4^{c}$ & 0.03 & $0.6^{\mathrm{b}}$ & 0.01 & $\star \star$ & NS & $\star \star$ \\
\hline$n-6$ & $6 \cdot 7^{\mathrm{C}}$ & 0.2 & $6 \cdot 6^{c}$ & 0.1 & $8 \cdot 4^{\mathrm{a}}$ & 0.1 & $7.9^{b}$ & 0.1 & * & $\star *$ & * \\
\hline $18: 3 n-3$ & $0.6^{\mathrm{c}}$ & 0.02 & $0.9^{b}$ & 0.04 & $0.9^{\mathrm{a}, \mathrm{b}}$ & 0.04 & $1.0^{\mathrm{a}}$ & 0.1 & $\star *$ & ** & ** \\
\hline $18: 4 n-3$ & $0.4^{\mathrm{d}}$ & 0.01 & $1 \cdot 3^{\mathrm{a}}$ & 0.04 & $0.5^{c}$ & 0.01 & $0.9^{\mathrm{b}}$ & 0.03 & $\star \star$ & ** & ** \\
\hline $20: 4 n-3$ & $0.3^{\mathrm{c}}$ & 0.1 & $1 \cdot 1^{\mathrm{a}}$ & 0.1 & $0.5^{b}$ & 0.1 & $1.0^{\mathrm{a}}$ & 0.1 & ** & NS & * \\
\hline $20: 5 n-3$ & $1.4^{\mathrm{d}}$ & 0.02 & $7 \cdot 4^{\mathrm{a}}$ & 0.1 & $1.9^{c}$ & 0.1 & $4 \cdot 8^{\mathrm{b}}$ & $0 \cdot 1$ & $\star *$ & $* *$ & $\star *$ \\
\hline $22: 5 n-3$ & $0.6^{\mathrm{d}}$ & 0.01 & $2 \cdot 8^{a}$ & 0.1 & $0.8^{\mathrm{c}}$ & 0.01 & $2 \cdot 0^{\mathrm{b}}$ & $0 \cdot 1$ & $\star *$ & ** & ** \\
\hline $22: 6 n-3$ & $5 \cdot 9^{c}$ & 0.1 & $13 \cdot 6^{\mathrm{a}}$ & 0.2 & $8 \cdot 4^{b}$ & 0.3 & $13 \cdot 4^{\mathrm{a}}$ & $0 \cdot 1$ & $\star *$ & ** & $\star *$ \\
\hline$n-3$ & $9 \cdot 2^{\mathrm{d}}$ & 0.1 & $27 \cdot 8^{a}$ & 0.1 & $13 \cdot 2^{c}$ & 0.2 & $23 \cdot 6^{\mathrm{b}}$ & 0.1 & ** & NS & ** \\
\hline PUFA & $16 \cdot 5^{\mathrm{d}}$ & 0.3 & $36 \cdot 8^{\mathrm{a}}$ & 0.3 & $22 \cdot 3^{\mathrm{C}}$ & 0.1 & $33 \cdot 1^{\mathrm{b}}$ & 0.2 & ** & $\star \star *$ & ** \\
\hline SFA:PUFA & $3.2^{\mathrm{b}}$ & 0.1 & $0.7^{\mathrm{a}}$ & 0.01 & $1.8^{\mathrm{C}}$ & 0.04 & $0.8^{\mathrm{a}}$ & 0.02 & ** & ** & ** \\
\hline$\Sigma F A$ & $96 \cdot 3$ & & 94.2 & & 95.9 & & 94.4 & & & & \\
\hline
\end{tabular}

HF, high-fat; LF, low-fat; CO, coconut oil; FO, fish oil; FA, fatty acid.

a,b,c,d Mean values within a row with unlike superscript letters showed a significant interaction between the two tested factors (FS $v$. FL; $P<0.05)$.

$P$ value for FS, FL and interaction between the main effects of the two tested factors (FS $v$. FL): ${ }^{\star} P<0.05 ;{ }^{\star *} P<0.01$ (two-way ANOVA). 
(A)

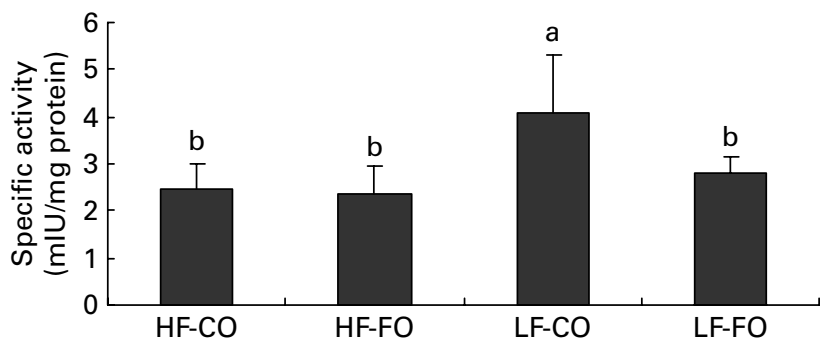

(B)

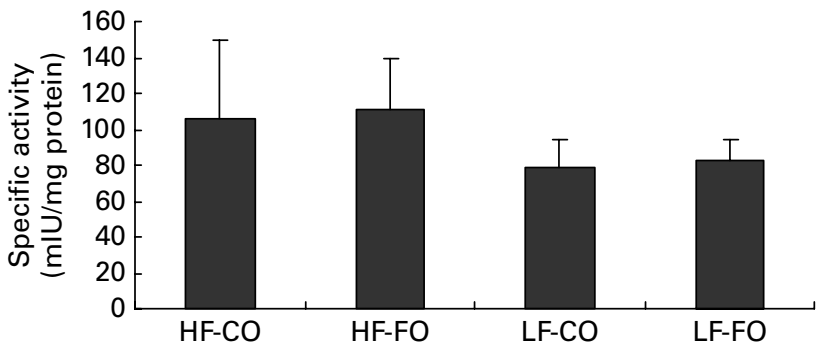

Fig. 2. Postprandial $(7 \mathrm{~h})$ specific activities of $(\mathrm{A})$ fatty acid synthase ( $\mathrm{mlU} / \mathrm{mg}$ protein) and (B) 3-hydroxyacyl-CoA dehydrogenase ( $\mathrm{mlU} / \mathrm{mg}$ protein) in the liver of rainbow trout fed during the 15-week feeding trial with different fat sources (FS: coconut oil (CO) or fish oil (FO)) and fat levels (FL: high fat (HF) or low fat (LF)). Values are means, with standard deviations represented by vertical bars, $n$ 9. Statistical significance for the two independent factors, FS and FL, and their interaction are as follows: (A) FS, $P<0.05$; FL, $P<0.01$; FS $\times \mathrm{FL}, P<0.05$; (B) FS, $P=0.66$; FL, $P<0.01 ; \mathrm{FS} \times \mathrm{FL}, P=0.96$. Mean values with no unlike letters indicates no significant interaction between the two dietary factors (FS $v$. FL; $P>0.05)$. ${ }^{\text {a,b }}$ Mean values with unlike letters were significantly different $(P<0.05)$.

Levels of plasma glucose, TAG and NEFA at 7 and $46 \mathrm{~h}$ after the meal are presented in Table 5. The replacement of FO by CO did not affect plasma glucose levels but significantly increased plasma TAG at $7 \mathrm{~h}$ and NEFA at $46 \mathrm{~h}$ after the meal. Feeding the HF diets compared with the LF diets increased circulating NEFA, TAG and also glucose at $46 \mathrm{~h}$. In addition, NEFA were affected by the interaction between the FS and the FL at $7 \mathrm{~h}$, being higher in fish fed the HF-CO diet. Plasma acetoacetate levels were significantly affected by the interaction between the FS and the FL, in particular $46 \mathrm{~h}$ after the last meal (Table 5).

\section{Discussion}

Enhanced satiety and reduced food intake have been reported in homeotherms fed diets containing C12-rich CO or other sources of $\mathrm{MCFA}^{(3-5)}$. In teleosts, data on the effect of dietary MCT on voluntary food intake are limited. However, the negative relationship between food intake and the MCT load (a 1:1 blend of C8:C10) in Atlantic salmon ${ }^{(16)}$ agrees with the appetite-suppressive effect of MCT reported in mammals. Similarly, food intake of polka-dot grouper fed a diet containing $15 \% \mathrm{CO}$, equivalent to the amount used in the present study, dropped by $50 \%$ compared with the FO-based control diet, whereas the $30 \%$ CO level reduced intakes to such an extent that growth was severely compromised ${ }^{(21)}$. In contrast, the CO diets in the present study only slightly (3\%) reduced food intake when expressed on an individual basis, and not at all when corrected for the metabolic body weight of the rainbow trout. This absence of an inhibitory effect of $\mathrm{CO}$ on food intake has also been shown in sunshine bass in which food intake (percentage of whole body weight) was unaffected by the replacement of $15 \%$ FO by $10 \%$ CO and $5 \%$ palm oil ${ }^{(20)}$. In that study, fish fed the CO diet had, however, reduced growth, in line with other findings in fish fed $\mathrm{MCT}^{(19,21)}$. In contrast, the final body weight of the present rainbow trout, which increased five-fold during the 15-week feeding trial, was not affected by the presence of CO, irrespective of its level ( 5 or $15 \%$ ). Regarding the effect of the dietary FL, trout fed the HF diets had a higher final body weight, mainly related to the higher amount of body fat as expected from other studies with salmonids ${ }^{(28,29)}$. Importantly, food intake or energy intake was not reduced by the high energy level of the HF diets. This contrasts with reports that rainbow trout adjust food intake so as to ingest a fixed amount of digestible energy ${ }^{(30-32)}$, but agrees with our previous observations that food intake in (rapidly) growing rainbow trout is not retro-inhibited by the dietary fat or energy level when fed a diet non-limiting in protein ${ }^{(33)}$

The gut is the first organ involved in the signalling of hunger and satiety induced by the dietary nutrient supply. CCK, secreted by the proximal intestine, has been documented to suppress food intake in many species $^{(34)}$ including fish $^{(35)}$. Also in rainbow trout, indirect evidence suggests an anorectic role for CCK, as shown by enhanced feeding following administration of CCK receptor antagonists ${ }^{(36)}$. In rainbow trout, three putative CCK- 8 peptides, CCK-N, CCK-L and CCK-T (containing a different amino acid in position 6 from the C-terminal), have been identified, with the CCK-L and CCK-T transcripts being predominantly detected in the entire gut $^{(37)}$. In fish, information on intestinal gene expressions of CCK as a function of nutritional status is limited to the comparison of fed $v$. starved fish, showing that starvation decreases intestinal CCK gene expression in yellowtail ${ }^{(38)}$, but not significantly in Atlantic salmon $(\mathrm{CCK}-\mathrm{L} / \mathrm{N})^{(39)}$. Besides, in fish, only one study so far has quantified changes in plasma CCK in response to diet composition, showing an increased amount of circulating CCK in rainbow trout fed HF diets, consistent with its presumed role as a satiety agent ${ }^{(40)}$. To our knowledge, there are no further data in teleosts on the postprandial regulation of CCK release (gene expression or circulating levels) by the dietary FL or fatty acid profile. Using a murine enteroendocrine cell line, C12, given as NEFA, has been reported to induce an acute CCK release ${ }^{(41)}$, whereas the finding that intraduodenal infusion of $\mathrm{C} 12$ relative to $\mathrm{C} 18$ in human subjects did not modify CCK secretion suggests that CCK is not directly responsible for the satiating effect of C12 ${ }^{(42)}$. Furthermore, when supplied as a TAG, long-chain TAG appear to be more effective in stimulating CCK release than $\mathrm{MCT}^{(43)}$, which has been attributed to the rapid absorption and hence lower exposure time of MCT to the foregut. Also in the present study, rainbow trout fed the longchain TAG-rich HF-FO diet displayed increased postprandial CCK-T transcript levels, however, without reducing the fed 
(A)

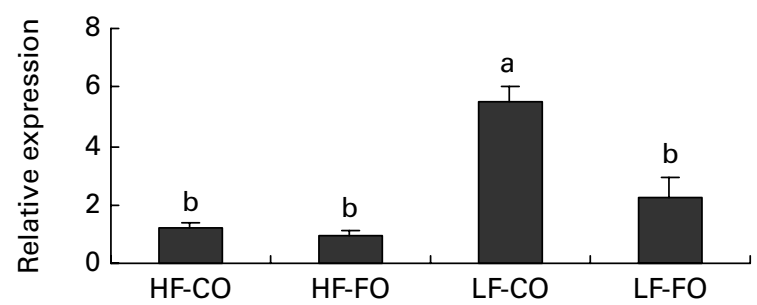

(C)

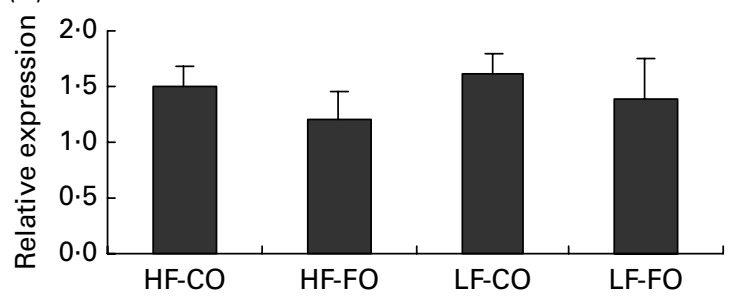

(E)

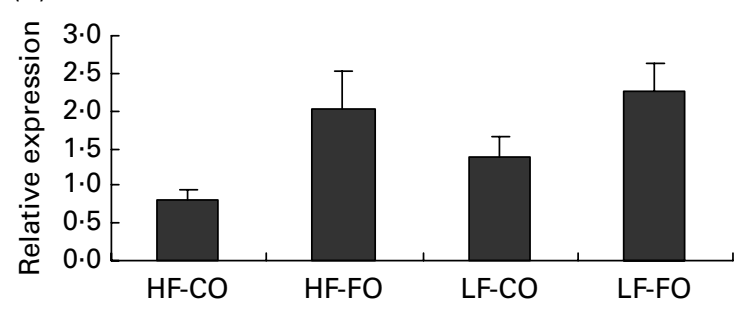

(G)

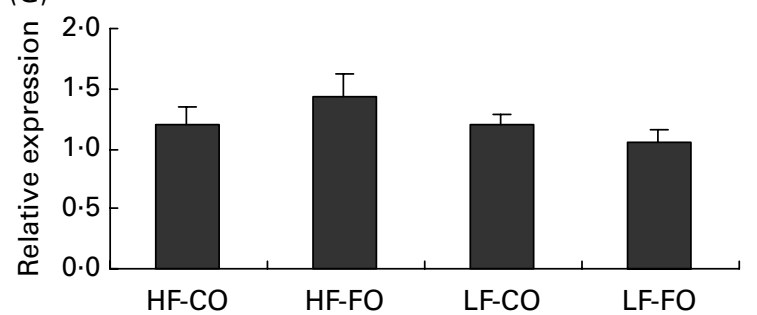

(B)

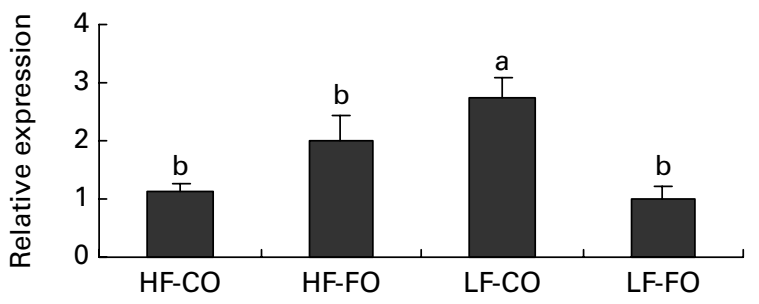

(D)
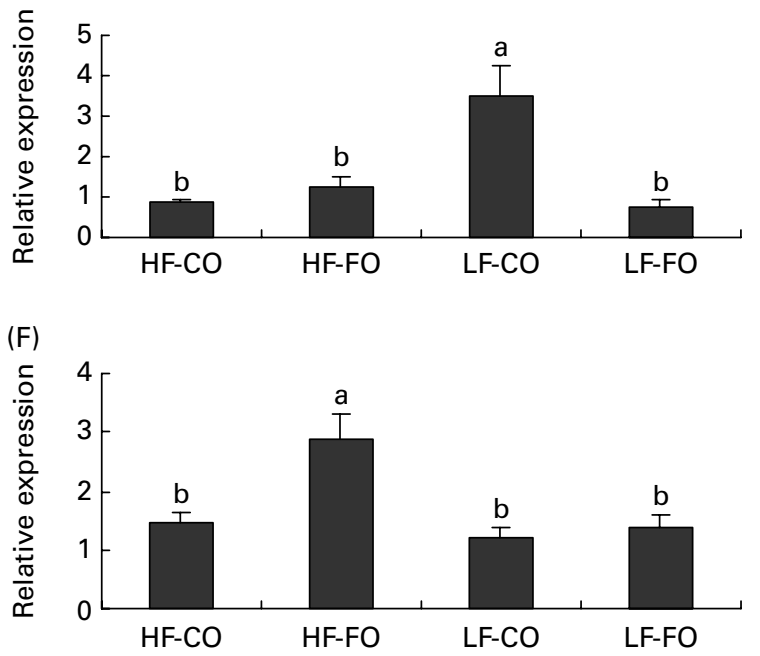

(H)

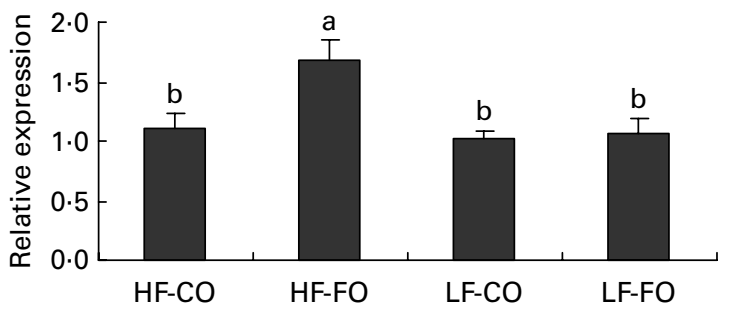

Fig. 3. Postprandial $(7 \mathrm{~h})$ expression of selected genes (A) fatty acid synthase, (B) fatty-acyl-chain elongase protein 3, (C) delta-6-desaturase, (D) stearoyl-CoA desaturase, $(E)$ carnitine palmitoyl transferase $1 \mathrm{a},(\mathrm{F})$ carnitine palmitoyl transferase Ib, $(\mathrm{G})$ 3-hydroxyacyl-CoA dehydrogenase and $(\mathrm{H})$ acyl-CoA oxidase in the liver of rainbow trout fed during the 15-week feeding trial with different fat sources (FS: coconut oil (CO) or fish oil (FO)) and fat levels (FL: high fat (HF) or low fat (LF)). Values are means, with their standard errors represented by vertical bars, $n$ 9. Expression values are normalised to the expressed elongation factor $1 \alpha$ transcripts. Statistical significance for the two independent factors, FS and FL, and their interaction are as follows: (A) FS, $P<0.01 ; \mathrm{FL}, P<0.01 ; \mathrm{FS} \times \mathrm{FL}$, $P<0.01$; (B) FS, $P=0.19$; FL, $P=0.33$; FS $\times \mathrm{FL}, P<0.01$; (D) FS, $P<0.05$; FL, $P<0.05$; FS $\times \mathrm{FL}, P<0.01$; (E) FS, $P<0.05 ; \mathrm{FL}, P=0.34 ; \mathrm{FS} \times \mathrm{FL}, P=0.68$; (F) FS, $P<0.01$; FL, $P<0.05$; FS $\times$ FL, $P<0.05$; (H) FS, $P<0.05$; FL, $P<0.05$; FS $\times F \mathrm{~F}, P<0.05$. Mean values with no unlike letters indicates no significant interaction between the two dietary factors (FS $v$. FL; $P>0.05)$. ${ }^{\mathrm{a}, \mathrm{b}}$ Mean values with unlike letters were significantly different $(P<0.05)$.

intake. On the other hand, CCK-L transcript levels were unaffected by the FS or FL, which coincides with the similarity in food intake in the four groups. Further studies on the dietary regulation of the gene expression and circulating levels of the different CCK- 8 peptides are necessary to elucidate the mediating role of CCK in food intake regulation in rainbow trout.

Evidence in mammals indicates that it is the metabolic utilisation of the ingested nutrients that determines satiety and feeding behaviour ${ }^{(11-13)}$. In this respect, it has been hypothesised that fat which is oxidised enhances satiety in contrast to fat which is stored. As such, the satiating effect of MCT has been explained by the small storage capacity of MCFA compared with $\operatorname{LCFA}^{(1,2)}$, reflected by the loss of adiposity, as shown in terrestrial vertebrates ${ }^{(6,7)}$ as well as in teleosts $^{(21,23)}$ fed MCT. Conversely, in the present study, the trout fed the CO and FO diets accumulated and retained (gain/intake) similar amounts of body lipids. Even more surprising is that the final whole-body fatty acid profile consisted for over 10 and $20 \%$ of $\mathrm{C} 12$ in trout ( $46 \mathrm{~h}$ starved) fed the LF-CO and HF-CO diets, respectively, compared with less than $1 \%$ in FO-fed trout. As a result, over $50 \%$ of the body fatty acids were saturated in HF-CO-fed rainbow trout, however, without visible detrimental effects on the fish. The substantial C12 retention (57\%) roughly indicates that more than half of the ingested $\mathrm{C} 12$ was stored, irrespective of the dietary CO level. This contrasts with low C12 retentions in 
(A)

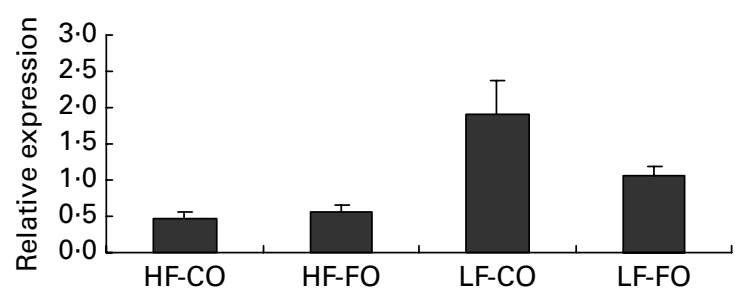

(C)

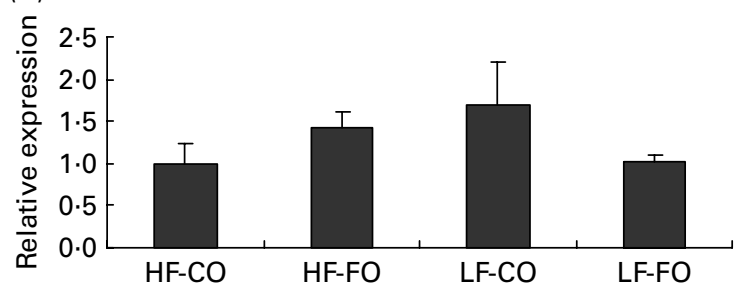

(B)

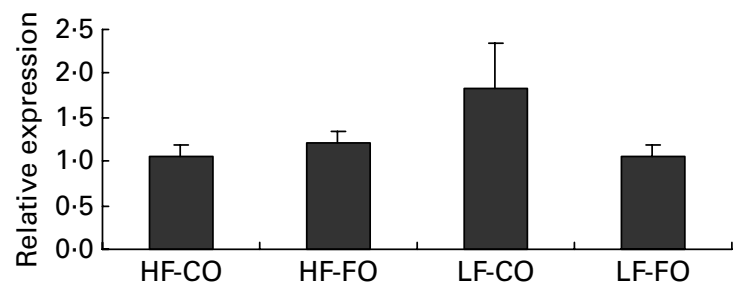

(D)

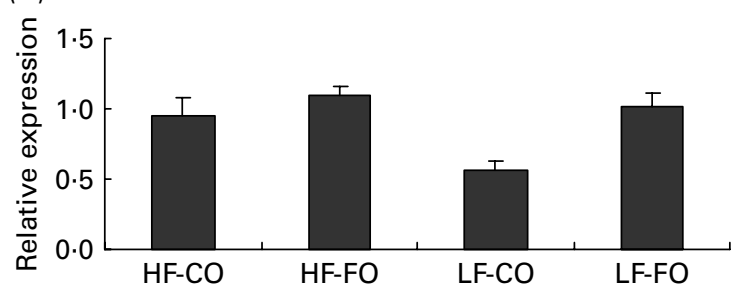

Fig. 4. Postprandial (7h) expression of selected genes (A) fatty acid synthase, (B) acyl-CoA oxidase, (C) carnitine palmitoyl transferase 1 a and (D) carnitine palmitoyl transferase $\mathrm{Ib}$ in the muscle of rainbow trout fed during the 15-week feeding trial with different fat sources (FS: coconut oil (CO) or fish oil (FO)) and fat levels (FL: high fat (HF) or low fat (LF)). Values are means, with their standard errors represented by vertical bars, $n$ 9. Expression values are normalised to the expressed elongation factor $1 \alpha$ transcripts. Statistical significance for the two independent factors, FS and FL, and their interaction are as follows: (A) FS, $P=0.11 ; \mathrm{FL}, P<0.05 ; \mathrm{FS} \times \mathrm{FL}, P=0.19$; (D) FS, $P<0.05 ; \mathrm{FL}, P<0.05 ; \mathrm{FS} \times \mathrm{FL}, P=0.10$. Mean values with no unlike letters indicates no significant interaction between the two dietary factors (FS $v$. FL; $P>0.05$ ).

rats $^{(8,9)}$ or in other fish such as the polka-dot grouper that diverted C12 mainly to oxidative pathways ${ }^{(18,21,23)}$, but agrees with reports in some other teleosts ${ }^{(14,20)}$ and also in infants ${ }^{(44)}$ suggesting that body lipids contained considerable amounts of MCFA. Besides, feeding red drum ${ }^{(22)}$ with MCT did not alter their total body lipid contents. As in mammals ${ }^{(2)}$, feeding the CO diets activated fatty acid synthesis pathways, reflected here by increased levels of $16: 0,18: 0,16: 1$ and $18: 1$ in the body lipids of the trout. Accordingly, CO stimulated the transcription of enzymes involved in fatty acid synthesis (FAS) and fatty acid elongation/desaturation (fattyacyl-chain elongase protein 3 and SCD) in liver, although significant only at the low incorporation level (interaction between the FS and the FL). Yet, the present experimental diet design does not allow to distinguish whether the latter changes result from a higher $\mathrm{CO}$ or from a lower FO supply, taking into account the inhibitory effect of PUFA on FAS ${ }^{(45)}$ and $\mathrm{SCD}^{(46)}$. Enhanced lipogenesis in trout fed $\mathrm{CO}$ is also suggested by the elevated level of circulating TAG, as seen in mammals following chronic MCT consumption ${ }^{(47)}$. On the other hand, reduced FAS in skeletal muscle and liver with both HF diets corroborates the inhibitory effect of increased dietary lipid (and/or decreased dietary starch) on lipogenic activity, as documented earlier in teleosts ${ }^{(48)}$ and found here to be independent of the fatty acid profile.

The hypothesis of a lower satiating power of lipids when stored rather than oxidised ${ }^{(11-13)}$ has received little attention in teleosts, but has been proposed to explain the absence of food intake adjustments according to the digestible energy level in a foregoing study with rainbow trout fed increasing amounts of $\mathrm{FO}^{(33)}$. A common point between the latter and the present study, apart from the fact that food intake in both studies appeared to be unregulated by the dietary lipid level, is that the dietary protein level largely covered the requirements for lean body growth (as determined by the genetic growth potential and experimental conditions). This allows, at least to a certain extent, the storage of the fat ingested in excess, which, according to Friedman ${ }^{(11)}$, might in turn explain why FO is not being perceived as satiating by the fast-growing trout ${ }^{(33)}$. The present results extend this idea in that the similar lipid retention and hence the apparent lack of a preferential oxidation of MCFA possibly account for the absence of a suppressive effect of $\mathrm{CO}$ on food intake in the present study. In contrast, the satiating effect of MCT in rodents has been attributed to increased hepatic fatty acid oxidation and hepatic ATP content ${ }^{(3,4,10)}$. The role of hepatic fatty acid oxidation in the control of food intake has been evidenced in studies with rats, where portal mercaptoacetate injection, which suppresses fatty acid oxidation by inhibiting acyl-CoA dehydrogenases, abolished the feeding-inhibitory effect of high lipid ${ }^{(13)}$ or $\mathrm{MCT}^{(3,4)}$. In rats, further evidence of the importance of hepatic fatty acid oxidation in the control of food intake is given in a study, in which the administration of methylpalmoxirate, which blocks CPT1 and thus mitochondrial LCFA oxidation, stimulated food intake in rats when fed a diet rich in long-chain TAG but not when fed a diet rich in $\mathrm{MCT}^{(10)}$, probably because MCFA do not require CPT1 to enter the mitochondria. In fish, no study has so far compared the effects of MCFA and LCFA on specific markers of fatty acid oxidation. Earlier studies in rainbow trout have demonstrated the existence of at least one gene encoding CPT1, showing a protein sequence identity of 63 and $61 \%$ with human L- and M-CPT1 ${ }^{(49)}$. Later work in rainbow trout has identified different CPT1 isoforms, designated as a, b, c or $\mathrm{d}$ (our laboratory ${ }^{(28)}$ ) or as multiple $\alpha$ - and $\beta$-isoforms ${ }^{(50)}$. The present data confirm the presence of both CPT1a and b isoforms in the skeletal muscle and liver of rainbow trout $^{(28,51)}$. Moreover, the increased level of CPT1 transcripts 
(except for muscle CPT1-a) in liver and skeletal muscle when fed FO compared with CO probably confirms the higher dependency of LCFA than MCFA on CPT1 to enter the mitochondria $^{(10)}$. In liver, this effect on CPT1-b was significant only at high FO supply, whereas in skeletal muscle, both fatty acid type (LCFA) and lipid level (HF) enhanced its expression. The up-regulation of CPT1-b transcription by dietary lipid and the tissue-specificity of the dietary regulation of the different CPT1 isoforms corroborate previous observations in rainbow trout ${ }^{(28,51,52)}$. The apparent lower dependency of MCFA on CPT1 transcription was, however, not accompanied by enhanced mitochondrial fatty acid oxidation as suggested by similar hepatic HAD activity and expression in CO- and FO-fed fish. In addition, feeding MCFA neither increased hepatic peroxisomal fatty acid oxidation, measured by ACOX expression, despite some reports on the importance of peroxisomes in the catabolism of lauric acid and MCFA in mammals ${ }^{(2)}$ or fish ${ }^{(53)}$. The above findings are consistent with the apparent absence of preferential CO oxidation in trout as suggested by the body composition analyses. Conversely, the high $v$. low lipid supply increased the hepatic activity of HAD and ACOX expression, in line with previous findings in trout $^{(28)}$

In mammals fed high-MCT loads, the enhanced delivery of NEFA to the liver and their subsequent oxidation to acetyl-CoA favour the production of ketone bodies (acetoacetate and $\beta$-hydroxybutyrate), which are assumed to play a role in the satiating effect of $\mathrm{MCT}^{(2)}$. The concentrations of acetoacetate found here $(0.2-0.4 \mathrm{~mm})$ are within the range of values reported earlier in rainbow trout ${ }^{(54)}$ or sea bass ${ }^{(55)}$. The higher plasma acetoacetate in trout fed the MCT-rich diet (HF-CO) was, however, not associated with a reduced food intake (corrected for the metabolic body weight of the fish). This might be related to the fact that NEFA represents a more relevant energy fuel for fish brain than ketone bodies $^{(55)}$. The question whether higher levels of ketone bodies induced by higher MCT levels repress food intake warrants, however, further investigation in rainbow trout and other teleosts.

Another interesting point concerns the fasted ( $46 \mathrm{~h}$ ) plasma glucose levels, being higher in trout fed the HF diets compared with LF diets, particularly with the HF-CO diet. Since the HF diets contained $10 \%$ less starch than the LF diets, circulating glucose was expected to be lower in HF-fed trout at 7 and $46 \mathrm{~h}$ after the meal. The opposite trend between dietary starch and postprandial glucose may reflect impaired glucose tolerance, as found in mammals fed high dietary lipid ${ }^{(56)}$. This observation deserves specific attention, especially considering the poor glucose utilisation and prolonged postprandial hyperglycaemia in rainbow trout ${ }^{(57)}$ and the development of metabolic disorders associated with impaired food intake regulation in mammals chronically fed HF $\operatorname{diets}^{(56)}$.

The present 15-week feeding study shows that a dietary supply of MCT, in the form of CO, does not reduce food intake in rainbow trout. In contrast to observations in terrestrial vertebrates, which attributed the satiating effect of $\mathrm{CO}$ to the rapid oxidation and low retention of $\mathrm{C} 12$, rainbow trout was found to deposit a large part and elongate/ desaturate some of the C12 to longer-chain fatty acids rather than readily oxidise it, which may explain the failure of MCT in creating a satiety effect in rainbow trout.

\section{Acknowledgements}

This study was funded by institutional INRA funds. A. C. F.-S. acknowledges the postdoctoral INRA fellowship (MRI, Package INRA-WUR Aquaculture Platform, Crédits CDD 9C). There are no conflicts of interest. We thank Y. Hontang and F. Sandres (INRA Donzacq experimental fish farm) and C. Vachot for their technical assistance. I. G., S. K. and A. C. F.-S. designed the research; F. T. conducted the feed trial and analysed the growth data; A. C. F.-S. performed the biochemical and molecular analyses, interpreted the results and wrote the manuscript together with I. G.; S. S. K., J. W. S. and F. M. contributed to the interpretation and presentation of the experimental data. All authors contributed to and approved the manuscript.

\section{References}

1. Marten B, Pfeuffer M \& Schrezenmeir J (2006) Medium-chain triglycerides. Int Dairy J 16, 1374-1382.

2. Papamandjaris AA, MacDougall DE \& Jones PJH (1998) Medium chain fatty acid metabolism and energy expenditure: obesity treatment implications. Life Sci 62, 1203-1215.

3. Ooyama K, Kojima K, Aoyama T, et al. (2009) Decrease of food intake in rats after ingestion of medium-chain triacylglycerol. J Nutr Sci Vitaminol 55, 423-427.

4. Stubbs RJ \& Harbron CG (1996) Covert manipulation of the ratio of medium- to long-chain triglycerides in isoenergetically dense diets: effect on food intake in ad libitum feeding men. Int J Obes 20, 435-444.

5. Van Wymelbeke V, Himaya A, Louis-Sylvestre J, et al. (1998) Influence of medium-chain and long-chain triacylglycerols on the control of food intake in men. Am J Clin Nutr $\mathbf{6 8}$, 226-234.

6. Crozier G, Boisjoyeux B, Chanez M, et al. (1987) Metabolic effects induced by long-term feeding of medium-chain triglycerides in the rat. Metab Clin Exp 36, 807-814.

7. St-Onge MP, Bosarge A, Goree LLT, et al. (2008) Medium chain triglyceride oil consumption as part of a weight loss diet does not lead to an adverse metabolic profile when compared to olive oil. J Am Coll Nutr 27, 547-552.

8. Johnson RC, Young SK, Cotter R, et al. (1990) Mediumchain-triglyceride lipid emulsion - metabolism and tissue distribution. Am J Clin Nutr 52, 502-508.

9. Lhuillery C, Mebarki S, Lecourtier MJ, et al. (1988) Influence of different dietary fats on the incorporation of exogenous fatty-acids into rat adipose glycerides. J Nutr $\mathbf{1 1 8}$, 1447-1454.

10. Friedman MI, Ramirez I, Bowden CR, et al. (1990) Fuel partitioning and food intake: role for mitochondrial fatty acid transport. Am J Physiol 258, 216-221.

11. Friedman MI (1998) Fuel partitioning and food intake. $A m J$ Clin Nutr 67, 513S-518S.

12. Friedman MI, Harris RB, Ji H, et al. (1999) Fatty acid oxidation affects food intake by altering hepatic energy status. Am J Physiol Regul Integr Comp Physiol 276, R1046-R1053.

13. Scharrer E \& Langhans W (1986) Control of food intake by fatty acid oxidation. Am J Physiol 250, 1003-1006. 
14. Davis DA, Lazo JP \& Arnold CR (1999) Response of juvenile red drum (Sciaenops ocellatus) to practical diets supplemented with medium chain triglycerides. Fish Physiol Biochem 21, 235-247.

15. Fontagné S, Corraze G \& Bergot P (2000) Response of common carp (Cyprinus carpio) larvae to different dietary levels and forms of supply of medium-chain fatty acids. Aquat Living Resour 13, 429-437.

16. Nordrum S, Olli JJ, Rosjo C, et al. (2003) Effects of graded levels of medium chain triglycerides and cysteine on growth, digestive processes and nutrient utilization in sea water reared Atlantic salmon (Salmo salar, L.) under ad libitum feeding regime. Aquacult Nutr 9, 263-274.

17. Olsen RE, Henderson RJ \& Ringo E (1998) The digestion and selective absorption of dietary fatty acids in Arctic charr, Salvelinus alpinus. Aquacult Nutr 4, 13-21.

18. Smith DM, Williams IH, Williams KC, et al. (2005) Oxidation of medium-chain and long-chain fatty acids by polka dot grouper Cromileptes altivelis. Aquacult Nutr 11, 41-48.

19. Stickney RR \& Andrews JW (1972) Effects of dietary lipids on growth, food conversion, lipid and fatty acid composition of channel catfish. J Nutr 102, 249-258.

20. Trushenski JT (2009) Saturated lipid sources in feeds for sunshine bass: alterations in production performance and tissue fatty acid composition. North Am J Aquacult 71, 363-373.

21. Williams I, Williams KC, Smith DM, et al. (2006) Polkadot grouper, Cromileptes altivelis, can utilize dietary fat efficiently. Aquacult Nutr 12, 379-387.

22. Craig SR \& Gatlin DM (1995) Coconut oil and beef tallow, but not tricaprylin, can replace menhaden oil in the diet of red drum (Sciaenops ocellatus) without adversely affecting growth or fatty-acid composition. J Nutr 125, 3041-3048.

23. Fontagné S, Pruszynski T, Corraze G, et al. (1999) Effect of coconut oil and tricaprylin vs. triolein on survival, growth and fatty acid composition of common carp (Cyprinus carpio L.) larvae. Aquaculture 179, 241-251.

24. Rosjo C, Nordrum S, Olli JJ, et al. (2000) Lipid digestibility and metabolism in Atlantic salmon (Salmo salar) fed medium-chain triglycerides. Aquaculture 190, 65-76.

25. NRC (National Research Council) (2011) Nutritional Requirements of Fish and Srimp, pp. 376. Washington, DC: The National Academies Press USA.

26. Figueiredo-Silva AC, Corraze G, Kaushik S, et al. (2010) Modulation of blackspot seabream (Pagellus bogaraveo) intermediary metabolic pathways by dispensable amino acids. Amino Acids 39, 1401-1416.

27. Mellanby J \& Williamson DH (1974) Acetoacetate. In Methods of Enzymatic Analysis, pp. 1841-1843 [HU Bergmeyer, editor]. New York, NY: Academic Press.

28. Kolditz C, Borthaire M, Richard N, et al. (2008) Liver and muscle metabolic changes induced by dietary energy content and genetic selection in rainbow trout (Oncorbynchus mykiss). Am J Physiol Regul Integr Comp Physiol 294, R1154-R1164.

29. Jobling M, Koskela J \& Savolainen R (1998) Influence of dietary fat level and increased adiposity on growth and fat deposition in rainbow trout, Oncorbynchus mykiss (Walbaum). Aquacult Res 29, 601-607.

30. Boujard T \& Médale F (1994) Regulation of voluntary feed intake in juvenile rainbow trout fed by hand or by selffeeders with diets containing two different protein energy/ ratios. Aquat Living Resour 7, 211-215.

31. Gélineau A, Corraze G, Boujard T, et al. (2001) Relation between dietary lipid level and voluntary feed intake, growth, nutrient gain, lipid deposition and hepatic lipogenesis in rainbow trout. Reprod Nutr Dev 41, 487-503.
32. Yamamoto T, Shima T, Unuma T, et al. (2000) Voluntary intake of diets with varying digestible energy contents and energy sources, by juvenile rainbow trout Oncorbynchus mykiss, using self-feeders. Fish Sci 66, 528-534.

33. Geurden I, Gondouin E, Rimbach M, et al. (2006) The evaluation of energy intake adjustments and preferences in juvenile rainbow trout fed increasing amounts of lipid. Physiol Behav 88, 325-332.

34. Moran TH \& Kinzig KP (2004) Gastrointestinal satiety signals II. Cholecystokinin. Am J Physiol Gastrointest Liver Physiol 286, 183-188.

35. Volkoff H, Canosa LF, Unniappan S, et al. (2005) Neuropeptides and the control of food intake in fish. Gen Comp Endocrinol 142, 3-19.

36. Gelineau A \& Boujard $T$ (2001) Oral administration of cholecystokinin receptor antagonists increase feed intake in rainbow trout. $J$ Fish Biol 58, 716-724.

37. Jensen H, Rourke IJ, Moller M, et al. (2001) Identification and distribution of CCK-related peptides and mRNAs in the rainbow trout, Oncorbynchus mykiss. Biochim Biophys Acta 1517, 190-201

38. Murashita K, Fukada H, Hosokawa H, et al. (2006) Cholecystokinin and peptide $\mathrm{Y}$ in yellowtail (Seriola quinqueradiata): molecular cloning, real-time quantitative RT-PCR, and response to feeding and fasting. Gen Comp Endocrinol 145, 287-297.

39. Murashita K, Kurokawa T, Nilsen TO, et al. (2009) Ghrelin, cholecystokinin, and peptide YY in Atlantic salmon (Salmo salar): molecular cloning and tissue expression. Gen Comp Endocrinol 160, 223-235.

40. Jonsson E, Forsman A, Einarsdottir IE, et al. (2006) Circulating levels of cholecystokinin and gastrin-releasing peptide in rainbow trout fed different diets. Gen Comp Endocrinol 148, 187-194.

41. Benson RSP, Sidhu SS, Jones MN, et al. (2002) Fatty acid signalling in a mouse enteroendocrine cell line involves fatty acid aggregates rather than free fatty acids. $J$ Physiol 538, $121-131$.

42. Feltrin KL, Little TJ, Meyer JH, et al. (2008) Comparative effects of intraduodenal infusions of lauric and oleic acids on antropyloroduodenal motility, plasma cholecystokinin and peptide YY, appetite, and energy intake in healthy men. Am J Clin Nutr 87, 1181-1187.

43. Hopman WPM, Jansen J, Rosenbusch G, et al. (1984) Effect of equimolar amounts of long-chain triglycerides and mediumchain triglycerides on plasma cholecystokinin and gallbladder contraction. Am J Clin Nutr 39, 356-359.

44. Sarda P, Lepage G, Roy CC, et al. (1987) Storage of mediumchain triglycerides in adipose-tissue of orally fed infants. Am J Clin Nutr 45, 399-405.

45. Clark SD (2000) Polyunsaturated fatty acid regulation of gene transcription: a mechanism to improve energy balance and insulin resistance. BrJ Nutr 83, 59-66.

46. Waters KM \& Ntambi JM (1996) Polyunsaturated fatty acids inhibit hepatic stearoyl-CoA desaturase-1 gene in diabetic mice. Lipids 31, S33-S36.

47. Pfeuffer M \& Schrezenmeir J (2002) Milk lipids in diet and health - medium chain fatty acids (MCFA). Bull Int Dairy Fed 377, 32-42.

48. Sargent JR, Henderson RJ \& Tocher DR (2002) The lipids. In Fish Nutrition, pp. 182-246 [ JE Halver and RW Hardy, editors]. San Diego, CA: Academic Press.

49. Gutieres S, Damon M, Panserat S, et al. (2003) Cloning and tissue distribution of a carnitine palmitoyltransferase I gene in rainbow trout (Oncorbynchus mykiss). Comp Biochem Physiol 135B, 139-151. 
50. Morash AJ, Le Moine CMR \& McClelland GB (2010) Genome duplication events have led to a diversification in the CPT I gene family in fish. Am J Physiol Regul Integr Comp Physiol 299, R579-R589.

51. Polakof S, Medale F, Skiba-Cassy S, et al. (2010) Molecular regulation of lipid metabolism in liver and muscle of rainbow trout subjected to acute and chronic insulin treatments. Domest Anim Endocrinol 39, 26-33.

52. Morash AJ, Bureau DP \& McClelland GB (2009) Effects of dietary fatty acid composition on the regulation of carnitine palmitoyltransferase (CPT) I in rainbow trout (Oncorbynchus mykiss). Comp Biochem Physiol 152B, 85-93.

53. Henderson RJ \& Sargent JR (1985) Chain-length specificities of mitochondrial and peroxisimal [beta]-oxidation of fatty acids in livers of rainbow trout (Salmo gairdneri). Comp Biochem Physiol 82B, 79-85.

54. Phillips JW \& Hird FJR (1977) Ketogenesis in vertebrate livers. Comp Biochem Physiol 57B, 133-138.

55. Zammit VA \& Newsholme EA (1979) Activities of enzymes of fat and ketone-body metabolism and effects of starvation on blood-concentrations of glucose and fat fuels in teleosts and elasmobranch fish. Biochem J 184, 313-322.

56. Miesel A, Muller H, Thermann M, et al. (2010) Overfeedinginduced obesity in spontaneously hypertensive rats: an animal model of the human metabolic syndrome. Ann Nutr Metab 56, 127-142.

57. Enes P, Panserat S, Kaushik S, et al. (2009) Nutritional regulation of hepatic glucose metabolism in fish. Fish Physiol Biochem 35, 519-539. 